DOI: 10.17951/lrp.2021.40.4.263-274

\title{
ZENON GAJDZICA
}

Uniwersytet Śląski w Katowicach

ORCID - 0000-0002-6329-411X

\section{Magdalena BeŁZa-Gajdzica}

Uniwersytet Śląski w Katowicach

ORCID - 0000-0002-1316-6689

\section{WSPÓŁPRACA MIEJSKICH I WIEJSKICH SZKÓŁ OGÓLNODOSTĘPNYCH Z PLACÓWKAMI SPECJALNYMI}

Wprowadzenie: Podnoszenie jakości edukacji włączającej jest warunkowane wieloma czynnikami. Jednym z wykorzystywanych w wielu krajach jest wsparcie udzielane szkołom głównego nurtu przez budowanie partnerstwa ze szkołami specjalnymi i korzystanie z ich zasobów. W artykule skoncentrowano się na zagadnieniu współpracy szkół ogólnodostępnych i specjalnych postrzeganej z perspektywy kadry tych pierwszych. Dodatkowo podjęto się rozpatrzenia omawianego partnerstwa w aspekcie środowiska (wiejskiego i miejskiego) szkoły ogólnodostępnej. Cel badań: Celem badań było rozpoznanie form współpracy szkół ogólnodostępnych i specjalnych zawartych w deklaracjach kadry pedagogicznej szkół ogólnodostępnych oraz określenie związku intensywności wskazań współpracy z lokalizacją (wiejską i miejską) placówek ogólnodostępnych. Metoda badań: W badaniach została zastosowana metoda sondażu diagnostycznego. Do zebrania danych został wykorzystany kwestionariusz ankiety skierowany do ogólnodostępnych szkół podstawowych. Na potrzeby artykułu zostało przeanalizowane pytanie o dobre praktyki stosowane w celu budowania kultury włączającej szkoły. W toku badania uzyskano 2548 odpowiedzi (1498 ze szkół wiejskich oraz 1046 z miejskich, w 4 przypadkach zabrakło informacji o ulokowaniu szkoły - te placówki zostały wyłączone $\mathrm{z}$ badania). $\mathrm{Z}$ odpowiedzi wyselekcjonowano deklaracje dotyczące współpracy szkół głównego nurtu z placówkami specjalnymi. Wyniki: Analiza danych ukazała nikły poziom współpracy. Jedynie 2,01\% szkół miejskich oraz 1,87\% szkół wiejskich zadeklarowało różne formy współpracy z placówkami specjalnymi. W znacznej większości dotyczyły one wspólnego organizowania wydarzeń o charakterze integrującym. Środowisko (wiejskie/miejskie) praktycznie nie różnicuje poziomu współpracy. Wnioski: Kreowanie współpracy (jak wynika z analizy literatury przedmiotu korzystnej dla obu typów placówek) wymaga rozwiązań systemowych inicjujących różne formy partnerstwa oraz stworzenia zbioru bodźców (np. w postaci projektów) zachęcających do systematycznej współpracy. 
Słowa kluczowe: wiejska i miejska szkoła ogólnodostępna, placówka specjalna, współpraca, partnerstwo

\section{WPROWADZENIE}

Kwestia współpracy (partnerstwa) szkół specjalnych i ogólnodostępnych wpisuje się w cztery, powiązane ze sobą, nurty zagadnień. Pierwszy dotyczy wspierania procesów włączania uczniów z niepełnosprawnościami w placówkach ogólnodostępnych. Jest to nurt bogato ilustrowany przykładami i badaniami (Forlin, Rose, 2010; Hornby, 2014; Hornby, 2015; Shaw, 2017; Avvisar, 2017). Drugi obszar tematyczny obejmuje problematykę spójności systemu edukacji - realizowania koherentnych celów i zarazem promowania edukacji wysokiej jakości wszystkich uczniów w całym systemie (Ferguson, 2008; Haug, 2017). Trzeci - obejmuje zagadnienia przeobrażania roli szkól specjalnych w systemie edukacji (Norwich, 2008). Czwarty nurt, stosunkowo najrzadziej podejmowany w literaturze przedmiotu, obejmuje zagadnienie kreowania inkluzyjności szkół specjalnych. Warto dodać, że ten niedoceniany obszar zwykle jest traktowany jako wątek poboczny, podejmowany na marginesie prowadzonych analiz dotyczących partnerstwa obu typów placówek (Forlin, Rose, 2010; Shaw, 2017). W praktyce wskazane cztery nurty przenikają się wzajemnie, co wydaje się oczywiste w aspekcie złożoności i wielowątkowości działań podejmowanych w obszarze partnerstwa. Jako przykład może posłużyć jedna z nielicznych propozycji współpracy obu typów placówek sformułowana jeszcze w latach 80. ubiegłego wieku na gruncie polskim przez Aleksandra Hulka (1980, s. 495-496). Cytowany autor dostrzegał potencjał możliwej współpracy w kilku zakresach, m.in.: zatrudniania kadry szkół specjalnych w szkołach „zwykłych”, wykorzystywania przez te placówki sprzętu szkół specjalnych, czy korzystania z usług kadry specjalistycznej szkoły „zwykłej” (lekarzy, psychologów, pedagogów) przez szkoły specjalne. Proponowane działania lokują się zatem w obszarze wzmacniania jakości kształcenia uczniów włączanych w szkołach ogólnodostępnych, przypisują nową ( $w$ omawianym okresie) rolę szkołom specjalnym, a zarazem, w pewnym stopniu, służą również kreowaniu ich inkluzyjności poprzez wzmacnianie kontaktów z placówkami ogólnodostępnymi.

W opracowaniu koncentrujemy się na kwestii współpracy szkół ogólnodostępnych i specjalnych postrzeganej z perspektywy kadry tych pierwszych, co nieuniknione, nawiązując kontekstowo także do pozostałych obszarów. Dodatkowo podejmujemy się rozpatrzenia omawianego partnerstwa w aspekcie środowiska (wiejskiego i miejskiego) szkoły ogólnodostępnej. 


\section{PROBLEM I CEL BADAŃ}

Celem badań jest rozpoznanie i rozpatrzenie form współpracy szkół ogólnodostępnych i specjalnych zawartych w deklaracjach kadry pedagogicznej szkół ogólnodostępnych. Problematykę tę rozpatrujemy także w aspekcie środowiska (wiejskiego i miejskiego) placówek ogólnodostępnych.

Główny problem badawczy został zatem zawarty w pytaniu: jakie formy współpracy z placówkami specjalnymi deklarują dyrektorzy i nauczyciele szkół ogólnodostępnych? Formy te rozprujemy w aspekcie środowiska, co wyraża pytanie: jak środowisko (wiejskie/miejskie) szkoły ogólnodostępnej różnicuje deklaracje współpracy z placówkami specjalnymi?

\section{METODA BADAŃ I CHARAKTERYSTYKA PRÓBY}

Identyfikacja współpracy/partnerstwa szkół ogólnodostępnych i specjalnych stanowi element szerszego projektu badawczego, pt. Badanie praktyki ogólnodostępnych szkót podstawowych w zakresie edukacji włączającej (2020). Głównym celem projektu była identyfikacja dobrych praktyk podstawowych szkół ogólnodostępnych i integracyjnych urzeczywistnianych w realizacji edukacji włączającej oraz poznanie opinii badanych na temat uwarunkowań edukacji włączającej wysokiej jakości (Gajdzica i in., 2021). W artykule prezentujemy dane wykraczające poza zakres informacji opublikowanych w raporcie (Gajdzica i in., 2021) oraz dokonujemy ich systematyzacji w aspekcie środowiska (wiejskiego i miejskiego) - zmiennej nierozpatrywanej w projekcie.

W celu zebrania danych została wykorzystana metoda sondażu diagnostycznego - techniki ankiety. Kwestionariusz ankiety składający się z 17 pytań został rozpowszechniony przez MEN. Do analiz prowadzonych w artykule zostało wykorzystane jedno pytanie otwarte dotyczące charakterki dobrych praktyk realizowanych na rzecz budowania kultury szkoły włączającej. W toku badania uzyskaliśmy 2548 odpowiedzi (1498 ze szkół wiejskich oraz 1046 z miejskich, w 4 przypadkach zabrakło informacji o ulokowaniu szkoły - te placówki zostały wyłączone z badania). Z danych GUS wynika, że w roku szkolnym 2019/2020 w polskim systemie oświaty działało 13440 szkół podstawowych (z wyłączeniem szkół specjalnych), z tego 5067 w miastach i 8373 na wsi (Oświata i wychowanie w roku szkolnym 2019/2020. Aneks: tablica 3.6., 2020). Ujęta w próbie badawczej liczba szkół wiejskich i miejskich odzwierciedla zatem ogólne proporcje liczby szkół podstawowych funkcjonujących w Polsce. 


\section{PROCEDURA ANALIZY DANYCH}

Spośród 2544 odpowiedzi zostały wyselekcjonowane te, które wśród praktyk budowania kultury włączającej wymieniły przynajmniej jedną dotyczącą współpracy z placówką specjalną (szkołą specjalną, OREW, SOSW). Informacje te zostały uporządkowane zgodnie z uproszczoną klasyfikacją zakresów współpracy zidentyfikowaną w badaniach jakościowych (Bełza-Gajdzica, Gajdzica, 2021). Zaprezentowana w tabeli 2 typologia działań podejmowanych w ramach współpracy nie jest w pełni rozłączna, co wydaje się oczywiste w aspekcie złożoności poszczególnych działań i realizowaniu w ich zakresie różnych celów. Niemniej jednak z wypowiedzi badanych można było wnioskować o celach wiodących, które stały się głównym wskaźnikiem zakwalifikowania działania do określonego typu.

W efekcie bardzo nielicznej liczby wskazań zrezygnowaliśmy z analizy statystycznej (korelacji oraz siły związku), ograniczając się do prezentacji danych surowych, które w naszym przekonaniu w sposób wystarczający ilustrują omawiany problem.

\section{WYNIKI}

Praktyki obejmujące współpracę szkół ogólnodostępnych z placówkami specjalnymi - jak wynika z analizy danych przedstawionych w tabeli 1 - kształtują się niezwykle skromnie. Uśredniając - działania takie są podejmowane w jednej na pięćdziesiąt szkół. Ujęcie procentowe deklaracji wskazuje, że nieco częściej współpracę podejmują placówki miejskie. Niemniej jednak nieznaczna różnica pokazuje, że lokalizacja (wiejska/miejska) szkoły ogólnodostępnej praktycznie nie różnicuje natężenia omawianych praktyk.

Tabela 1.

Deklaracje współpracy szkót ogólnodostępnych i placówek specjalnych

\begin{tabular}{|c|c|c|c|c|c|c|}
\hline \multirow{2}{*}{ Lokalizacja } & \multicolumn{2}{|c|}{ Deklaracja współpracy } & \multicolumn{2}{|c|}{$\begin{array}{c}\text { Brak deklaracji współ- } \\
\text { pracy }\end{array}$} & \multicolumn{2}{c|}{ Razem } \\
\cline { 2 - 7 } & $N$ & $\%$ & $N$ & $\%$ & $N$ & 100 \\
\hline \multirow{2}{*}{ Szkoła miejska } & 21 & 2,01 & 1925 & 97,99 & 1046 & 100 \\
\hline Szkoła wiejska & 28 & 1,87 & 1470 & 98,13 & 1498 & 198 \\
\hline
\end{tabular}

Źródło: badania własne. 
Przywołane przez badanych dobre praktyki obejmujące konkretne działania podejmowane w ramach współpracy zostały zaprezentowane w tabeli 2. Ogólna skromna liczba deklaracji dotycząca współpracy przekłada się na incydentalne jej występowanie w poszczególnych typach. Najczęściej realizowaną praktyką jest organizowanie wspólnych imprez, zwykle o charakterze ludycznym, np. festyny, pikniki lub/i ukierunkowanym na kształtowanie postaw, np. dni godności osób z niepełnosprawnością, dni autyzmu. W kilkunastu przypadkach respondenci nie dookreślili działań i celów współpracy, wpisując jedynie, że jest ona podejmowana. Pozostałe typy współpracy występują incydentalnie. Analiza danych pokazuje zatem, że stosunkowo rzadko podejmowana współpraca ogranicza się (z nielicznymi wyjątkami) do wspólnych przedsięwzięć organizacyjnych. Z kolei współpraca merytoryczna, związana np. z realizacją wspólnych projektów, konsultacje metodyczne, wspólne zajęcia edukacyjne dla uczniów obu typów placówek - praktycznie nie jest realizowana.

Tabela 2.

Zadeklarowane kategorie współpracy szkół ogólnodostępnych i placówek specjalnych

\begin{tabular}{|l|c|c|c|}
\hline \multicolumn{1}{|c|}{ Typy współpracy } & $\begin{array}{c}\text { Szkoła miejska } \\
(N)\end{array}$ & $\begin{array}{c}\text { Szkoła wiejska } \\
(N)\end{array}$ & $\begin{array}{c}\text { Ogółem } \\
(N)\end{array}$ \\
\hline Organizowanie wspólnych imprez & 11 & 15 & 26 \\
\hline Współpraca bez dookreślenia & 7 & 6 & 13 \\
\hline Wspólne projekty edukacyjne & 1 & 2 & 3 \\
\hline Konsultacje merytoryczne & 2 & 0 & 2 \\
\hline $\begin{array}{l}\text { Działania charytatywne na rzecz } \\
\text { placówki specjalnej }\end{array}$ & 1 & 1 & 2 \\
\hline Wspólne działania charytatywne & 1 & 1 & 1 \\
\hline Wolontariat w placówce specjalnej & 0 & 1 & 1 \\
\hline Wspólne zajęcia edukacyjne & 1 & 0 & \\
\hline
\end{tabular}

Źródło: badania własne.

\section{DYSKUSJA WYNIKÓW}

Z danych prezentowanych przez Ministerstwo Edukacji Narodowej (Model edukacji dla wszystkich, 2020, s. 12) wynika, że 70\% uczniów z orzeczeniem o potrzebie kształcenia specjalnego realizuje obowiązek szkolny w placówkach ogólnodostępnych. W aspekcie szeroko pojętej edukacji włączającej należy także pamiętać o uczniach $\mathrm{z}$ innych grup defaworyzowanych, np.: dzieciach imigrantów i uchodźców, wywodzących się z rodzin o niskim statusie ekonomicznym, z zaburzeniami 
emocjonalnymi, parcjalnymi trudnościami w uczeniu się, charakteryzujących się trudnościami z identyfikacją własnej płci itp. Nie może więc dziwić, że obecnie aż 30\% wszystkich uczniów szkół ogólnodostępnych jest objętych różnymi formami pomocy psychologiczno-pedagogicznej (Model edukacji dla wszystkich, 2020, s. 12). Można zatem stwierdzić, że w praktycznie w każdej szkole ogólnodostępnej edukacja włączająca jest faktem. Tymczasem szkoły głównego nurtu, w wielu wymiarach, nie są przygotowane do urzeczywistniania edukacji włączającej. Kluczowym problemem jest barak merytorycznych i metodycznych kompetencji nauczycieli (zwłaszcza przedmiotu) do pracy z grupą zróżnicowaną (Janiszewska-Nieścioruk, 2016; Chrzanowska, 2019; Skotnicka, 2019; Gajdzica, 2020) oraz ich niewystarczające przygotowanie diagnostyczne (Kochanowska, 2015; Uberman, Mach, 2016; Skibska, Borzęcka, Twaróg-Kanus, 2020). Ponadto nauczyciele wskazują na brak wsparcia metodycznego (Gajdzica, 2020; Nowak, 2020) oraz niedobory w zakresie specjalistów realizujących zadania terapeutyczne i opiekuńcze (Skotnicka, 2019; Nowak, 2020). W tej sytuacji konieczna jest nie tylko potrzeba zmiany kształcenia nauczycieli, ale także poszukiwanie systemowego wsparcia ukierunkowanego na podnoszenie jakości edukacji wszystkich uczniów w placówkach ogólnodostępnych. Jedną z możliwych w tym zakresie strategią, realizowaną z powodzeniem $\mathrm{w}$ wielu krajach, jest wykorzystywanie potencjału placówek specjalnych (Shaw, 2017).

Główne problemy podejmowane przez badaczy omawianej problematyki dotyczą przede wszystkim strategii i obszarów współpracy (Forlin, Rose, 2010), modeli współpracy (Avissar 2018), praktyk współpracy między nauczycielami (Venianaki, Zervakis, 2015), wiedzy przekazywanej przez nauczycieli szkół specjalnych nauczycielom szkół głównego nurtu oraz tego jak wiedza ta może przyczynić się do rozwoju inkluzyjnego środowiska (Hedegaard-Sørensen, Riis Jensen, Børglum Tofteng, 2017), czy nastawienia (gotowości, uznania potrzeby) współpracy nauczycieli obu typów placówek (Razalli, Hashim, Mamat, Ariffin, 2020). Brakuje natomiast opracowań statystycznych, które mogą stanowić punkt odniesienia do prezentowanych danych. Niemniej jednak praktycznie wszystkie przywołane opracowania wskazują na bezsprzeczne korzyści z omawianej współpracy, choć nie brakuje w nich także zagadnień identyfikujących bariery i ograniczenia.

Tymczasem, jak pokazuje analiza prezentowanych danych, w rodzimych realiach współpraca/partnerstwo obu typów placówek jest śladowe i ogranicza się przede wszystkich do działań współorganizowania wydarzeń ludycznych, promocyjnych, ewentualnie kreujących pożądane postawy wobec osób z niepełnosprawnościami. Autentyczna współpraca w zakresie tworzenia sieci wsparcia metodycznego, współdziałania w zakresie kreowania programów edukacyjno-terapeutycznych, rozwiązywania (lub zapobiegania) konkretnych problemów wychowawczych i edu- 
kacyjnych, tworzenia ścieżek rozwoju uczniów, diagnozowania, czy realizowania wspólnych projektów edukacyjnych praktycznie nie istnieje.

Za zaskakujące należy uznać wyniki wskazujące na porównywalny wskaźnik współpracy ogólnodostępnych szkół wiejskich i miejskich. Analiza przytaczanej literatury wskazuje, że partnerstwo jest budowane najczęściej między szkołami sąsiadującymi (Forlin, Rose, 2010). W praktyce oznacza to, że większe szanse na podejmowanie współpracy powinno charakteryzować praktyki szkół miejskich, ponieważ zdecydowana większość placówek specjalnych jest ulokowana właśnie w tym środowisku (Oświata i wychowanie w roku szkolnym 2019/2020. Aneks: tablica 3.12., 2020). Być może wyjaśnień tego stanu rzeczy należy poszukiwać w charakterze podejmowanej współpracy - przypomnijmy ograniczającym się przede wszystkim do współdziałania w organizowaniu wspólnych wydarzeń integrujących i ludycznych. Potwierdzenie tej tezy wymaga dodatkowych badań o charakterze jakościowym.

Warto podjąć próbę sformułowania wstępnych tez wyjaśniających zdiagnozowany w badaniu stan niezwykle skromnej współpracy szkół głównego nurtu i placówek specjalnych.

Podstawowym warunkiem korzystania z zasobów placówek specjalnych jest ich przeobrażenie (związane również z transformacją szkół głównego nurtu) ukierunkowane na realizację celów edukacyjnych we współpracy i podobny sposób (Norwich, 2008). Mimo tego, że system kształcenia specjalnego jest immanentną częścią ogólnego systemu edukacji (Sękowska, 1998), w rodzimych warunkach rozwijał się on - analogicznie jak w wielu innych krajach (Avissar, 2018) - hermetycznie. Dopiero rozwój integracyjnej formy kształcenia doprowadził do przenikania strategii edukacji specjalnej do szkół ogólnodostępnych. Warto jednak wspomnieć, że w wielu krajach Europy Zachodniej - już w latach 70. i 80. ubiegłego wieku - obecna była idea specjalnych i ogólnodostępnych szkół współpracujących (Szumski, 2004), na kanwie której rozwijała się współpraca obu typów placówek. Nie znalazła ona jednak uznania w polskich warunkach kulturowych i społecznych.

Dodatkowo niż demograficzny wkraczający do polskich szkół w pierwszej dekadzie lat dwutysięcznych wzmocnił praktyki konkurowania o uczniów z orzeczoną potrzebą kształcenia specjalnego, których obecność w szkołach głównego nurtu była podstawowym warunkiem organizowania oddziałów integracyjnych. Konkurencji tej sprzyjała (i sprzyja nadal) organizacja systemu oświaty - szkoły publiczne są prowadzone przez samorządy terytorialne (Ustawa o systemie oświaty $z$ dnia 7 września 1991 r., art. 3 pkt 5), przy czym szkoły podstawowe ogólnodostępne przez gminy, a specjalne - najczęściej przez powiaty.

Pomijając przyczynkowe opracowania, zwykle odwołujące się do doświadczeń innych krajów (np. Hulek, 1989; Szumski, 2004), problematyka partnerstwa obu typów placówek nie doczekała się szerszego opracowania naukowego czy meto- 
dycznego w polskiej literaturze. Brakuje zatem teoretycznych pobudek, w postaci opracowanych koncepcji, przykładów możliwych rozwiązań praktycznych, zachęcających dyrektorów i nauczycieli do podejmowania partnerstwa w praktyce.

Zdiagnozowana w badaniach znikoma liczba przykładów współpracy szkół głównego nurtu i placówek specjalnych nie może zaskakiwać również w aspekcie braku uregulowań formalnych chociażby w formie dyrektyw zachęcających do omawianego partnerstwa. Chociaż należy podkreślić, że problem ten został zauważony, a nawet uwydatniony $\mathrm{w}$ dwóch dokumentach przygotowanych pod egidą MEN w 2020 roku (zob. np. Model edukacji dla wszystkich, 2020; Wspieranie podnoszenia jakości edukacji włączajacej w Polsce, 2020). W pierwszym dokumencie została opracowana koncepcja Specjalistycznych Centrów Wspierania Edukacji Włączającej (SCWEW), konstruowanych na bazie wybranych szkół i ośrodków specjalnych. Zadania SCWEW w założeniu obejmują m.in. doradztwo i wspieranie wychowania, edukacji i rehabilitacji uczniów na terenie przedszkoli i szkół głównego nurtu (Model edukacji dla wszystkich, 2020, s. 56-60). Propozycja ta jest próbą wykorzystania potencjału szkół specjalnych do podnoszenia jakości edukacji włączającej. Z kolei w drugim dokumencie omawiana kwestia została odzwierciedlona w jednym z ośmiu podstawowych obszarów założeń podnoszenia jakości edukacji dla wszystkich - mianowicie w obszarze siódmym przyjmującym postać stwierdzenia: „Szkoły i placówki specjalne pełnią nową rolę, wspierając bezpośrednio kadrę szkół ogólnodostępnych w rozwijaniu praktyki włączającej" (Wspieranie podnoszenia jakości edukacji włączającej w Polsce, 2020, s. 7).

\section{WNIOSKI}

Współpraca szkół ogólnodostępnych i placówek specjalnych (postrzegana z perspektywy przedstawicieli szkół głównego nurtu) należy do praktyk incydentalnych.

1. Ogranicza się przede wszystkim do współpracy w zakresie podejmowania wspólnych inicjatyw organizacyjnych wydarzeń o różnym charakterze (najczęściej ludycznym, integrującym, ukierunkowanym na kreowanie pożądanych społecznie postaw wobec osób z niepełnosprawnościami).

2. Rzetelne partnerstwo ukierunkowane na tworzenia sieci wsparcia metodycznego, współdziałania w zakresie kreowania programów edukacyjno-terapeutycznych, rozwiązywania (lub zapobiegania) konkretnych problemów wychowawczych i edukacyjnych, tworzenia ścieżek rozwoju uczniów, diagnozowania, czy realizowania wspólnych projektów edukacyjnych - z nielicznymi wyjątkami nie zostało wskazane przez respondentów jako działania podejmowane na rzecz budowania kultury szkoły włączającej. 
3. Lokalizacja (wiejska/miejska) szkoły ogólnodostępnej nie różnicuje wskaźnika współpracy ogólnodostępnych szkół wiejskich i miejskich z placówkami specjalnymi.

Uwydatnione w literaturze przedmiotu niewystarczające kompetencje nauczycieli szkół ogólnodostępnych w zakresie pracy z grupą o zróżnicowanych potrzebach edukacyjnych, w obszarze diagnozowania specjalnych potrzeb edukacyjnych oraz prowadzenia wysokiej jakości pomocy psychologiczno-pedagogicznej zachęca do wykorzystywania zasobów placówek specjalnych. Obecnie brakuje mechanizmów systemowych tworzących zbiór bodźców do podejmowania autentycznego, systematycznego partnerstwa przynoszącego również korzyści dla uczniów i nauczycieli szkół specjalnych. Prócz stworzenia rozwiązań systemowych ważne jest także uświadomienie dyrektorom i nauczycielom obu typów placówek korzyści omawianej współpracy, co jest warunkiem koniecznym podejmowania oddolnych inicjatyw na rzecz kreowania spójnego modelu edukacji wysokiej jakości dla wszystkich, także tej w szkołach specjalnych.

\section{OGRANICZENIA BADAŃ}

Ograniczenia dotyczą przede wszystkim doboru grupy badanej. Zaprezentowane dane, mimo znaczącej próby badanej, nie muszą w pełni odzwierciedlać przeciętnego stanu badanej problematyki, ponieważ można przypuszczać, że kwestionariusz został wypełniony przede wszystkim przez przedstawicieli szkół aktywnych, kreujących kulturę szkoły włączającej oraz chętnie uczestniczących w badaniach naukowych. Zapewne w tych placówkach podejmuje się więcej praktyk na rzecz budowania kultury włączającej szkoły niż w pozostałych.

\section{BIBLIOGRAFIA}

Avvisar, G. (2017). Partnershipsbetween special and mainstream schools. Journal of Research in Special Educational Needs, 18(3), 149-156. https://doi.org/10.1111/1471-3802.12401

Bełza-Gajdzica, M., Gajdzica, Z. (2021). Dobre praktyki w zakresie współpracy szkoły ogólnodostępnej i specjalnej. Szkoła Specjalna. Złożone do recenzji.

Chrzanowska, I. (2020). Nauczyciele o szansach i barierach edukacji właczajacej. Warszawa: PWN.

Ferguson, D. (2008). International Trends in Inclusive Education: The Continuing Challenge to Teach One and Everyone. European Journal of Special Needs Education, 23(2), 109-120. https://doi.org/ 10.1080/08856250801946236 
Forlin, C., Rose, F. (2010). Authentic school partnerships for enabling inclusive education in Hong Kong. Journal of Research in Special Educational Needs, 10(1), 13-22. https://doi.org/10.1111/j.1471-3802.2009.01139.x

Gajdzica, Z., Skotnicka, B., Pawlik, S., Bełza-Gajdzica, M., Trojanowska, M., Prysak, D., Mrózek, S. (2021). Analiza praktyki szkolnej i charakterystyka szkoły efektywnie realizującej edukacje właczająca $w$ praktyce - raport z badań. Warszawa: MEiN. (w druku).

Gajdzica, Z. (2020). Uczeń z lekką niepełnosprawnościa intelektualna w szkole ogólnodostępnej. Nauczyciele o (nie)zmienianej sytuacji w kontekście kultury szkoły inkluzyjnej. Warszawa: PWN.

Haug, P. (2017). Understanding inclusive education: ideals and reality. Scandinavian Journal of Disability Research, 19(3), 206-217. https://doi.org/ 10.1080/15017419.2016.1224778

Hedegaard-Sørensen, L., Riis Jensen, C., Børglum Tofteng, D.M. (2017). Interdisciplinary Collaboration as a Prerequisite for Inclusive Education. European Journal of Special Needs Education, 33(2), 382-395. https://doi.org/10.1080/08856257.2017.1314113

Hornby, G. (2014). Inclusive Special Education: evidence-based practice for children with special educational needs and disabilities. New York: Springer.

Hornby, G. (2015). Inclusive special education: development of a new theory for the education of children with special educational needs and disabilities. British Journal of Special Education, 42(3), 234-256. https://doi.org/10.1111/1467-8578.12101

Hulek, A. (1980). Integracyjny system kształcenia i wychowania. W: A. Hulek (red.). Pedagogika rewalidacyjna (s. 492-506). Warszawa: PWN.

Janiszewska-Nieścioruk, Z. (2016). (Nie)dojrzałość proinkluzyjnych zmian w kształceniu osób z niepełnosprawnością. Niepełnosprawność. Dyskursy Pedagogiki Specjalnej, 22, 47-59.

Kochanowska, E. (2015). Samoocena nauczycieli w zakresie kompetencji diagnostycznych i pracy z dziećmi ze specjalnymi potrzebami edukacyjnymi na etapie edukacji wczesnoszkolnej. Niepetnosprawność. Dyskursy Pedagogiki Specjalnej, 20, 143-153.

Model edukacji dla wszystkich. (2020). Warszawa: MEN. Pobrane 1, Stycznia, 2021 z: https://www.gov.pl/web/edukacja-i-nauka/model-edukacji-dla-wszystkich

Norwich, B. (2008). SPECIAL SCHOOLS: What future for special schools and inclusion? Conceptual and professional perspectives. British Journal of Special Education, 33(3), 136-143. https://doi.org/10.1111/j.1467-8578.2008.00387.x

Nowak A. (2020). Edukacja włączająca w opiniach i ocenach nauczycieli: doniesienie z badań. Studia Pedagogiczne, 35, 169-181. https://doi.org/10.25951/4161

Oświata i wychowanie w roku szkolnym 2019/2020. Aneks: tablica 3.6. (2020). WarszawaGdańsk: GUS. Pobrane 1, Sierpnia, 2021 z: https://stat.gov.pl/obszary-tematyczne/ edukacja/edukacja/oswiata-i-wychowanie-w-roku-szkolnym-20192020,1,15.html 
Oświata i wychowanie w roku szkolnym 2019/2020. Aneks: tablica 3.12. (2020). Warszawa-Gdańsk: GUS. Pobrano 1, Sierpnia, 2021 z: https://stat.gov.pl/obszary-tematyczne/ edukacja/edukacja/oswiata-i-wychowanie-w-roku-szkolnym-20192020,1,15.html

Razalli, A.R., Hashim, A.T., Mamat, N., Ariffin, A. (2020). Collaborative Teaching between Special Education Teachers and Mainstream Teachers in Inclusive Education Program. International Journal of Academic Research in Business and Social Sciences, 10(8), 1055-1065. https://doi.org/10.6007/IJARBSS/v10-i8/7713

Sękowska, Z. (1998). Wprowadzenie do pedagogiki specjalnej. Warszawa: Wyd. Naukowe APS.

Shaw, A. (2017). Inclusion: the role of special and mainstream schools. British Journal of Special Education, 44(3), 292-312. https://doi.org/10.1111/1467-8578.12181

Skibska, J., Borzęcka, A., Twaróg-Kanus, A. (2020). Kompetencje diagnostyczne i terapeutyczne w percepcji nauczycieli szkół ogólnodostępnych, integracyjnych i specjalnych. Kraków: Impuls.

Skotnicka, B. (2019). Przygotowanie szkoły wiejskiej do edukacji inkluzyjnej. Bydgoszcz: Wyd. Uniwersytetu Kazimierza Wielkiego.

Szumski, G. (2004). Współczesne formy organizacji kształcenia a cele edukacji niepełnosprawnych. W: Z. Gajdzica. A. Klinik (red.). Wątki zaniedbane, zaniechane, nieobecne $w$ procesie edukacji $i$ wsparcia społecznego osób niepełnosprawnych (s. 153-162). Katowice: Wyd. UŚ.

Ubernam, M., Mach, A. (2016). Kompetencje nauczyciela edukacji wczesnoszkolnej w szkole ogólnodostępnej w pracy z dzieckiem z niepełnosprawnością. Lubelski Rocznik Pedagogiczny, XXXV(3), 165-186. https://doi.org/10.17951/lrp.2016.35.3.165 Ustawa o systemie oświaty z dnia 7 września 1991 r. Dz.U. z 1991 r. Nr 95, poz. 425. Venianaki, A., Zervakis, S. (2015). Collaboration Practices between Special Education Teachers and Mainstream Teachers in Secondary Education. Journal of Education \& Social Policy, 2(6), 41-46.

Wspieranie podnoszenia jakości edukacji włączającej w Polsce. (2020). Warszawa: MEN. Pobrane 1, Czerwca, 2020 z: https://www.gov.pl/web/edukacja/projekt-realizowany-w-ramach-program-wsparcia-reform-strukturalnych

\section{COLLABORATION OF URBAN AND RURAL MAINSTREAM SCHOOLS WITH SPECIAL EDUCATION FACILITIES}

Introduction: Improving the quality of inclusive education is determined by many factors. One of them, applied in many countries, is the support for mainstream schools by building a partnership with special schools and by making use of their resources. The article is focused 
on the issue of cooperation between mainstream schools and special ones, viewed from the standpoint of the staff of the former. What has been additionally undertaken is the examination of this partnership as regards the (rural and urban) environment of mainstream school. Research Aim: The studies were aimed at recognizing the forms of collaboration between mainstream and special schools comprised in the declarations of mainstream school staff, as well as specifying the relationship between the intensity of collaboration indications and the (rural and urban) location of mainstream schools.

Method: The studies were conducted with the use of diagnostic poll method. The data were collected with the use of a questionnaire for the staff of mainstream primary schools. For the needs of this article, the issue was analysed of good practices applied to build the inclusive culture of school. 2548 answers were obtained (1498 from rural and 1046 from urban schools, in 4 cases the location was not provided so these facilities were excluded from the research). From all the answers, the declarations were selected which concerned the cooperation of mainstream schools with special ones.

Results: An analysis of the data revealed a meagre level of cooperation. Only 2.01\% of urban and $1.87 \%$ of rural schools declared different forms of collaboration with special facilities. They mostly concerned the common organizing of integration events. The (rural / urban) environment practically does not differentiate the level of cooperation.

Conclusions: The building of cooperation (which, in the light of the analysed expert literature, is beneficial to both types of school) requires some systemic solutions that initiate various forms of partnership and the creation of a set of stimuli (e.g. in the form of projects) encouraging to regular cooperation.

Keywords: rural and urban mainstream school, special education facility, collaboration, partnership 